\title{
Lone Stars III
}

GHARLES N. PROTHRO TEXANA SERIES 

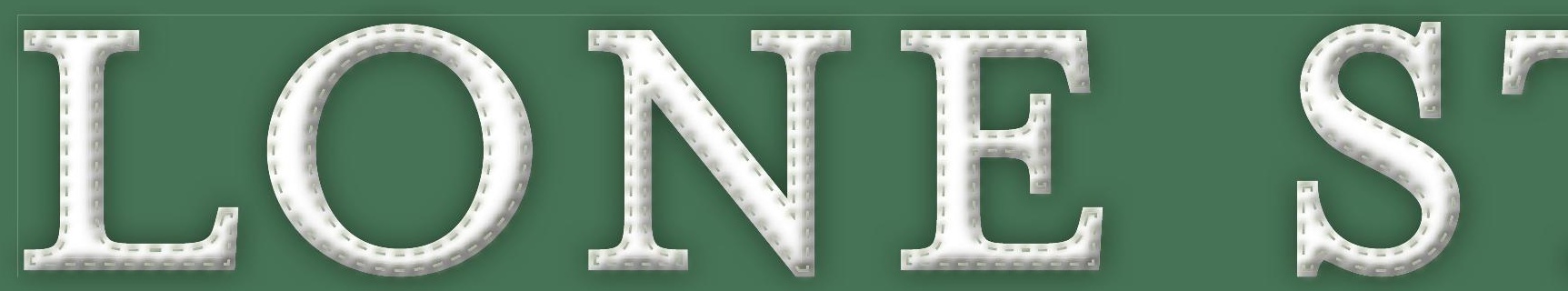

A Legacy of Texas Quilts, 1986-2011 

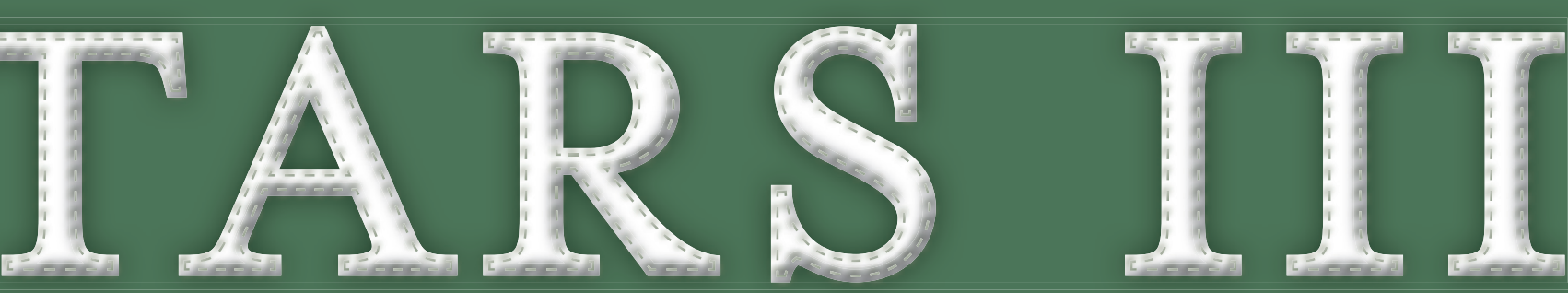

By KAROLINE PATTERSON BRESENHAN and NANGY O'BRYANT PUENTES 
Copyright (C) 20II by University of Texas Press All rights reserved Printed in China First edition, 20II

Designed by Ellen McKie
Requests for permission to reproduce material from this work should be sent to:

Permissions

University of Texas Press

P.O. Box 78I9

Austin, TX 78713-7819

www.utexas.edu/utpress/about/bpermission.html

( $)$ The paper used in this book meets the minimum requirements of ANSI/NISO Z39.48-1992 (R1997) (Permanence of Paper).

LIBRARY OF GONGRESS GATALOGING-IN-PUBLICATION DATA

Lone stars III : Texas quilts today / by Karoline Patterson Bresenhan and Nancy O'Bryant Puentes. - Ist ed.

p. $\quad$ cm. - (Charles N. Prothro Texana series)

Includes bibliographical references and index.

Summary: This volume, which covers I986-20II, completes the landmark documentation of 175 years of Texas quilt history that the authors began in Lone Stars I and II.

ISBN 978-0-292-72699-4 (cloth : alk. paper) - ISBN 978-0-292-72940-7 (pbk. : alk. paper) - ISBN 978-0-292-73556-9 (E-book)

I. Quilts-Texas-History-20th century-Catalogs. 2. Quilts-TexasHistory-2Ist century-Catalogs. I. Puentes, Nancy O'Bryant. II. Bresenhan, Karey, Lone stars. III. Title. IV. Title: Lone stars 3 : Texas quilts today.

$$
\begin{aligned}
& \text { NK9II2.B685 2OII } \\
& 746.4609764^{\prime} \text { 'O } 74-\mathrm{dc2} 2
\end{aligned}
$$

2011009407 
To the men in our lives, who inspired us to believe we could do anything we wanted to do:
Our fathers, the late C. C. "Pat" Patterson and the late Hollis Vernon O’Bryant;

Our cousin and brother, Hollis Pearce O'Bryant;

And our husbands, Maurice Lee Bresenhan, Jr., and Carlos Daniel Puentes 